\title{
Plasma levels of apolipoprotein-E in residents of the European North of Russia
}

\author{
Anastasiya M Kaneva ${ }^{1 *}$, Evgeny R Bojko ${ }^{1}$, Natalya N Potolitsyna ${ }^{1}$ and Jon O Odland ${ }^{2}$
}

\begin{abstract}
Background: Apolipoprotein-E (apoE) is one of the metabolically active apoproteins and plays an important role in lipid metabolism. However, there are no data on levels of apoE in residents of the North in spite of the fact that specific features of lipid metabolism in the northerners are described. The present work was designed to study plasma levels of apoE in residents of the European North of Russia.
\end{abstract}

Methods: A total of 937 native residents of the European North of Russia (463 men and 474 women) aged 13-60 years were included in the study. ApoE concentrations in the blood plasma were measured by immunoturbidimetric method.

Results: Plasma levels of apoE in residents of the European North of Russia were low. ApoE concentrations below the defined normal values were detected in $57.0 \%$ of the men and in $59.2 \%$ of the women. The mean plasma levels of apoE did not significantly differ in men and women $(2.80 \mathrm{mg} / \mathrm{dl}$ vs $2.87 \mathrm{mg} / \mathrm{dl})$. Plasma apoE concentrations in residents of the European North of Russia changed with age. Plasma levels of apoE decreased from 13 to 21 years in men and from 13 to 35 years in women and then increased in both sexes $(p<0.001)$.

Conclusion: The limits of variation of plasma apoE levels in residents of the European North of Russia shift towards lower values. Plasma levels of apoE below normal values were observed in approximately half of investigation subjects.

Keywords: Apolipoprotein-E, Lipid metabolism, Age, The North, Adaptation

\section{Background}

Apolipoprotein-E (apoE) is a monomeric glycoprotein with 299 amino acid residues and $34 \mathrm{kDa}$ molecular mass [1]. The protein is a structural and functional constituent of plasma chylomicrons and very low density lipoproteins (VLDL) and their lipolytic degradation products (i.e. chylomicron remnants and intermediate density lipoproteins). ApoE is also found in some subfractions of high density lipoproteins (HDL) [2-4]. This apolipoprotein is synthesized in liver and extrahepatic tissues (brain, kidneys, adrenal glands, spleen, muscles, skin, macrophages, etc.). Plasma apoE is largely liver-derived $[5,6]$.

ApoE plays important role in lipid metabolism. The main function of apoE is to regulate uptake of lipoproteins from the circulation by receptor-mediated endocytosis [4,7]. ApoE also participates in the synthesis of

\footnotetext{
* Correspondence: amkaneva@mail.ru

${ }^{1}$ Institute of Physiology, Komi Science Center, Ural Branch of Russian Academy of Sciences, Pervomaiskaya av. 50, Syktyvkar 167982, Russia Full list of author information is available at the end of the article
}

some lipoproteins, in the transport and redistribution of lipids among various tissues including the cholesterol transport from peripheral tissues in the liver, in the reparation of nervous cells and the vascular wall. Moreover, this protein has been shown in vitro to have antioxidant and anti-inflammatory properties [5,8-16].

Considerable influence of apoE on the lipid profile has been shown in studies on apoE-deficient mice and transgenic rabbits expressing high levels of apoE. ApoEdeficient mice have extremely high lipid levels and massive amounts of cholesterol-rich $\beta$-VLDL, resulting in development of severe atherosclerotic lesions even on a normal diet [17-19]. On the other hand, high plasma levels of apoE may also be associated with increased risk of dyslipidemia. It is supposed that high levels of apoE increase atherosclerosis risk by stimulating hepatic VLDL production and inhibiting VLDL lipolysis. Thus there is an optimal range of plasma apoE levels that is maximally beneficial, and that levels above or below that 
range impose a risk rather than a benefit for atherosclerosis $[5,20]$. In normolipidemic subjects, normal values of plasma concentration of apoE are 3-7 mg/dl [4].

At present time, major attention is given to the studying of polymorphism of the apoE gene. There are three common alleles of the apoE gene $(\varepsilon 2, \varepsilon 3, \varepsilon 4)$ coding three isoforms (E2, E3, E4). Population studies have shown that apoE isoforms influence lipid and apolipoprotein levels and are important determinants of risk for the development of cardiovascular diseases [21-24]. Plasma apoE concentration is usually not taken into account in similar studies. However, it is known that levels of apoE can change or even mask the apoE gene polymorphism effects on lipid parameters [25,26]. Hence studying the apoE gene polymorphism effects on plasma lipid levels without taking into account apoE concentration could lead to confounding results. Meanwhile, influence of the apoE gene polymorphism on apoE levels was not always found [27,28]. Besides, the $\varepsilon 3$ allele in all populations is the most frequent, with a range of $67-80 \%$ [29]. So we consider that the intent attention to the apoE gene polymorphism and insufficient interest in levels of this protein might not be correct.

The data on biological variations of plasma apoE levels are contradictory [3,25,30-36]. There are not much data on concentration and influence of apoE on lipid profile in residents of the North in spite of the fact that specific features of lipid metabolism in the northerners were described $[37,38]$.

\section{Methods}

\section{Subjects and sampling}

Subjects were apparently healthy residents of the European North of Russia (natives from five areas of Komi Republic located between $62^{\circ}$ and $65^{\circ}$ North latitude, 68\% of Russians and $32 \%$ of Komi). The total number of subjects participating was 937; consisting of 463 men and 474 women aged between 13-60 years. The subjects of both sexes were divided into the following age groups: 13-15 years (71 boys and 80 girls), 17-21 years (97 men and 101 women), 22-35 years (101 men and 107 women), 36-45 years (90 men and 85 women), and 46-60 years (104 men and 101 women).

Participants were excluded from the study by the following criteria: (i) a body mass index (BMI) of 30 or greater (BMI = weight in kilograms divided by height in meters squared); (ii) total cholesterol concentration above $5.5 \mathrm{mmol} / \mathrm{l}$; (iii) triglycerides concentration above $1.8 \mathrm{mmol} / \mathrm{l}$; (iv) glucose concentration above $6.0 \mathrm{mmol} / \mathrm{l}$. All participants were considered as being free from serious and chronic illnesses at the time of the recruitment. Each subject gave written informed consent for participating in the study, which was approved by the ethics committee of Institute of Physiology, Komi
Science Center, Ural Branch of Russian Academy of Sciences.

A single blood sample of $5 \mathrm{ml}$ was taken by rapid venipuncture with minimum stasis in the morning at 9 am after an overnight fast of 12-13 h. The samples were collected into vacutainers (Becton Dickinson BP). Blood samples were centrifuged and plasma was placed into eppendorf microcentrifuge tubes and was stored at $-20^{\circ} \mathrm{C}$ until analysis.

\section{ApoE measurements}

ApoE concentration in the blood plasma was measured by immunoturbidimetric method using a kit from «Chronolab» (Switzerland, Cat. No 101-0550). The samples were analyzed immediately after thawing at $37^{\circ} \mathrm{C}$ in thermostatic bath Measurement of each sample was carried out in duplicate, and the mean was calculated. Absorbance of all samples was measured on the Power Wave-200 automated spectrophotometer (Bio-Tek Instruments, USA) at $340 \mathrm{~nm}$.

\section{Analytical procedures}

Total cholesterol, triglycerides, HDL-cholesterol and glucose concentrations in the blood plasma were determined using enzymatic methods on the Power Wave-200 automated spectrophotometer (Bio-Tek Instruments, USA) with commercially available kits («Chronolab», Switzerland).

\section{Statistical analysis}

Statistical analysis was performed with Statistica 6.0 (Statsoft, Tulsa, USA). Continuous variables are presented as median and interquartile range (25th and 75 th percentiles), and qualitative variables are expressed as relative frequencies. Continuous data were analyzed using the Mann-Whitney (for two groups) and the Kruskal-Wallis tests (for three and more groups). Where the Kruskal-Wallis test revealed significant effect, the Mann-Whitney test with Bonferroni correction for multiple comparisons was used to discern differences between groups. The chi-squared test was used for comparison of qualitative variables. Correlations between indices were assessed using the Spearman rank correlation. A value of $\mathrm{p}<0.05$ was accepted as statistically significant.

\section{Results}

Table 1 gives the baseline characteristics of the study subjects. All subjects had BMI, lipids and glucose levels within the laboratory normal range by virtue of the exclusion criteria. These parameters increased with age in both men and women $(\mathrm{p}<0.001)$.

Plasma concentrations of apoE in residents of the European North of Russia are presented in Table 2. In residents of the European North of Russia, there were no significant differences in plasma levels of apoE 
Table 1 The baseline characteristics in residents of the European North of Russia

\begin{tabular}{|c|c|c|c|c|c|c|}
\hline & $\mathrm{N}$ & Body mass index, $\mathrm{kg} / \mathrm{m}^{2}$ & Total cholesterol, $\mathrm{mmol} / \mathrm{l}$ & Triglycerides, mmol/l & HDL-cholesterol, mmol/l & Glucose, $\mathrm{mmol} / \mathrm{l}$ \\
\hline \multicolumn{7}{|c|}{ Men, $n=463$} \\
\hline 1 group & 71 & 19.2 & 3.75 & 0.83 & 1.06 & 3.83 \\
\hline $13-15$ years & & $(17.4 ; 21.3)$ & $(3.33 ; 4.20)$ & $(0.69 ; 1.02)$ & $(0.91 ; 1.27)$ & $(3.38 ; 4.63)$ \\
\hline 2 group & 97 & 19.4 & 3.55 & 0.93 & 0.99 & 3.99 \\
\hline $17-21$ years & & $(18.1 ; 20.9)$ & $(2.63 ; 4.09)$ & $(0.80 ; 1.10)$ & $(0.86 ; 1.39)$ & $(3.48: 4.60)$ \\
\hline 3 group & 101 & 25.1 & 4.05 & 1.16 & 1.29 & 4.41 \\
\hline $22-35$ years & & $(23.1 ; 26.9)$ & $(3.53 ; 4.56)$ & $(0.92 ; 1.33)$ & $(0.88 ; 1.51)$ & $(4.04 ; 4.84)$ \\
\hline 4 group & 90 & 25.4 & 4.46 & 1.13 & 1.35 & 4.49 \\
\hline $36-45$ years & & $(23.0 ; 27.5)$ & $(3.89 ; 4.86)$ & $(0.93 ; 1.36)$ & $(1.16 ; 1.62)$ & $(4.03 ; 4.88)$ \\
\hline 5 group & 104 & 26.7 & 4.31 & 1.02 & 1.42 & 4.56 \\
\hline $46-60$ years & & $(24.3 ; 28.4)$ & $(3.86 ; 4.75)$ & $(0.86 ; 1.20)$ & $(1.12 ; 1.62)$ & $(4.09 ; 5.08)$ \\
\hline$p$ value & & $<0.001$ & $<0.001$ & $<0.001$ & $<0.001$ & $<0.001$ \\
\hline \multicolumn{7}{|c|}{ Women, $n=474$} \\
\hline 1 group & 80 & 20.2 & 3.65 & 0.84 & 1.06 & 3.67 \\
\hline $13-15$ years & & $(18.4 ; 22.1)$ & $(3.27 ; 4.26)$ & $(0.70 ; 1.05)$ & $(0.95 ; 1.30)$ & $(3.17 ; 4.34)$ \\
\hline 2 group & 101 & 20.1 & 3.59 & 0.94 & 1.13 & 3.86 \\
\hline $17-21$ years & & $(18.0 ; 22.1)$ & $(3.11 ; 4.13)$ & $(0.81 ; 1.07)$ & $(0.96 ; 1.49)$ & $(3.42 ; 4.27)$ \\
\hline 3 group & 107 & 20.8 & 3.88 & 0.81 & 1.47 & 3.93 \\
\hline $22-35$ years & & $(19.1 ; 23.5)$ & $(3.58 ; 4.33)$ & $(0.69 ; 0.98)$ & $(1.05 ; 1.79)$ & $(3.43 ; 4.55)$ \\
\hline 4 group & 85 & 23.9 & 4.29 & 0.87 & 1.60 & 4.13 \\
\hline $36-45$ years & & $(21.3 ; 27.6)$ & $(3.84 ; 4.68)$ & $(0.68 ; 1.08)$ & $(1.13 ; 1.81)$ & $(3.73 ; 4.74)$ \\
\hline 5 group & 101 & 26.9 & 4.44 & 0.94 & 1.62 & 4.30 \\
\hline $46-60$ years & & $(25.4 ; 27.9)$ & $(4.03 ; 4.83)$ & $(0.80 ; 1.14)$ & $(1.41 ; 1.88)$ & $(3.92 ; 4.85)$ \\
\hline$p$ value & & $<0.001$ & $<0.001$ & $<0.001$ & $<0.001$ & $<0.001$ \\
\hline
\end{tabular}

Data are expressed as median (interquartile range).

$p$ value; Statistical significance of differences between age groups was estimated using the Kruskal-Wallis test.

Table 2 Plasma apolipoprotein-E levels $(\mathrm{mg} / \mathrm{dl})$ in residents of the European North of Russia by sex and age

\begin{tabular}{lccc}
\hline Age group & Men & Women & $\boldsymbol{p}^{\mathbf{1}}$ value \\
\hline Total & $2.80(1.97 ; 3.72)$ & $2.87(2.07 ; 3.65)$ & 0.652 \\
$13-60$ years & $\mathrm{n}=463$ & $\mathrm{n}=474$ \\
1 group & $2.70(1.91 ; 3.84)$ & $2.96(1.94 ; 3.68)$ \\
$13-15$ years & $\mathrm{n}=71$ & $\mathrm{n}=80$ \\
2 group & $2.19(1.57 ; 3.00)^{* 1-2}$ & $2.52(1.64 ; 3.29)$ \\
$17-21$ years & $\mathrm{n}=97$ & $\mathrm{n}=101$ \\
3 group & $2.35(1.66 ; 3.08)$ & $2.45(1.87 ; 3.25)$ \\
$22-35$ years & $\mathrm{n}=101$ & $\mathrm{n}=107$ \\
4 group & $2.98(2.23 ; 3.73)^{* * 2-4 ; 3-4}$ & $3.15(2.32 ; 3.86))^{* * 2-4 ; 3-4}$ \\
$36-45$ years & $\mathrm{n}=90$ & $\mathrm{n}=85$ \\
5 group & $\mathrm{n}=104$ & $3.11(2.39 ; 3.95)^{* * 2-5 ; 3-5}$ \\
$46-60$ years & $<0.001$ & $\mathrm{n}=101$ \\
$p^{2}$ value & $(2.88 ; 4.07)^{* 1-5 ; * * 2-5 ; 3-5}$ & $<.262$ \\
\hline
\end{tabular}

Data are expressed as median (interquartile range).

$p^{1}$ value; Statistical significance of differences between men and women was estimated using the Mann-Whitney test.

$p^{2}$ value; Statistical significance of differences between age groups was estimated using the Kruskal-Wallis test. Differences between age groups are statistically significant at: ${ }^{*}-p<0.05{ }^{* *}-p<0.01$ (the Mann-Whitney test with Bonferroni correction). 
between men and women $(\mathrm{p}=0.652)$. The results showed that the mean plasma apoE levels were $2.80 \mathrm{mg} / \mathrm{dl}$ in men and $2.87 \mathrm{mg} / \mathrm{dl}$ in women (Table 2). The analysis of individual data has shown that apoE concentrations below normal values were observed in $57.0 \%$ of the men and $59.2 \%$ of the women. The maximum deviation of plasma apoE levels from the lower limit of normal values reached $78.3 \%$ in men and $86.7 \%$ in women. There were no subjects with plasma levels of apoE above normal values. No significant differences in percentage of subjects with low and normal values of apoE between men and women were detected $\left(x^{2}=0.002 ; p=0.962\right)$.

Plasma levels of apoE in residents of the European North of Russia changed with age (Table 2). Plasma apoE concentrations were higher in the adolescent group (13-15 years) compared with subjects 17-35 years old. Men and women aged 17-21 years had apoE levels on $19 \%(\mathrm{p}=0.040)$ and $15 \%(\mathrm{p}=0.305)$ less than the adolescents. The significant increase of plasma apoE concentrations in residents of the European North of Russia was observed after age 35. The age-related increase of plasma apoE levels in men was simultaneously accompanied by significant decrease of number of subjects with apoE concentrations below normal values $\left(\chi^{2}=17.07\right.$; $\mathrm{p}=0.002$ ) (Table 3). The lowest percent of subjects with apoE levels below normal values was observed in the group after 45 years. In women the number of subjects with low values of apoE also tended to decrease with age but these changes were statistically insignificant $\left(\chi^{2}=7.01 ; \mathrm{p}=0.135\right)$.

Strong influence of age on BMI, lipids and glucose levels $(\mathrm{p}<0.001)$ was confirmed by means of the Spearman's rank correlation (Table 4). Meanwhile, apoE was correlated only with total cholesterol $\left(\mathrm{r}_{\mathrm{s}}=0.24 ; \mathrm{p}<0.001\right)$ in men and with total cholesterol $\left(\mathrm{r}_{\mathrm{s}}=0.15 ; \mathrm{p}<0.001\right)$ and triglycerides $\left(r_{s}=-0.10 ; p=0.037\right)$ in women. No significant correlation between plasma apoE levels and BMI was observed. These data indicate that age-related changes of

Table 3 The percentage of subjects with values of apolipoprotein-E below normal values in the age groups of residents of the European North of Russia

\begin{tabular}{ccc}
\hline Age group & Men (\%) & Women (\%) \\
\hline Total 13-60 years & 57.0 & 59.2 \\
13-15 years & 57.7 & 52.2 \\
17-21 years & 74.2 & 68.3 \\
22-35 years & 73.3 & 71.0 \\
36-45 years & 52.2 & 42.4 \\
46-60 years & 28.8 & 47.5 \\
$p$ value & 0.002 & 0.135 \\
\hline
\end{tabular}

Data are presented as percentage.

$p$ value; Statistical significance of differences between age groups was determined by Chi-square test.
Table 4 Correlation coefficients of age and plasma apolipoprotein-E levels with other covariates

\begin{tabular}{lcccc}
\hline & \multicolumn{2}{c}{ Men $(\mathbf{n}=\mathbf{4 6 3})$} & \multicolumn{2}{c}{ Women $(\mathbf{n}=\mathbf{4 7 4})$} \\
\hline Body mass index & $0.71^{* * *}$ & 0.05 & $0.55^{* * *}$ & -0.03 \\
Total cholesterol & $0.38^{* * *}$ & $0.24^{* * *}$ & $0.40^{* * *}$ & $0.15^{* * *}$ \\
Triglycerides & $0.33^{* * *}$ & -0.03 & $0.13^{* * *}$ & $-0.10^{*}$ \\
HDL-cholesterol & $0.30^{* * *}$ & 0.04 & $0.42^{* * *}$ & 0.05 \\
Glucose & $0.33^{* * *}$ & 0.07 & $0.30^{* * *}$ & 0.03 \\
apoE & $0.26^{* * *}$ & - & $0.18^{* * *}$ & - \\
\hline Correlations are statistically significant at: ${ }^{*}-\mathbf{p}<0.05 ;{ }^{* * *}-p<0.001$.
\end{tabular}

apoE concentrations in residents of the European North of Russia were associated to a certain extent with alterations of lipid profile whereas BMI did not influence apoE levels.

\section{Discussion}

Our results demonstrated that plasma apoE levels were not different between men and women. This fact is consistent with data from other studies [30-32]. At the same time, other authors have revealed presence of sex-related differences in apoE concentrations in humans. In some studies it has been demonstrated that apoE concentrations were higher in women, in others, apoE concentrations were higher in men $[3,33,34]$. It is suggested that sex hormones might cause the differences in apoE concentration between men and women [25]. Sex hormones are known to have multiple effects on lipid metabolism [39]. In particular, it has been determined that administration of estradiol to castrated male rats increased the level of apoE in lipoprotein fractions, whereas administration of testosterone to castrated female rats had the opposite effect [40]. Thus, it is possible to suppose that the hormonal status does not influence plasma apoE levels in residents of the European North of Russia or this effect is masked by other factors.

Age is supposed to be a significant factor for apoE level variation. Results of studies about age influence on apoE concentrations are conflicting. Several studies have demonstrated that apoE concentrations in blood decrease with age [41]. At the same time, there are data showing increase of apoE levels with age [33]. More detailed studies have shown that age ambiguously influences apoE concentrations in the process of maturing. Overall, apoE levels in blood decrease from birth and childhood until age 20-30 years. After age 30, apoE concentrations increase until age 60 years. The highest apoE concentrations are found between 50 and 60 years. The decrease of apoE levels was revealed after 60 years. Subjects older than 80 years have lower apoE concentrations (on 25\%) than the 50-60 year-old group [23, 31, 34,]. The age dynamics of plasma apoE levels in residents of the European North of Russia revealed by us correspond 
to age-related changes of apolipoprotein concentrations described above. In residents of the European North of Russia, plasma levels of apoE decreased from 13 to 21 years in men and from 13 to 35 years in women and then increased in both sexes. The observed increase of apoE levels with age was probably associated with agerelated changes of lipid metabolism. The increase of total cholesterol and triglycerides concentrations, the transformation of lipoprotein profile, the decrease of synthesis and number of apoB,E-receptors, the lowering of lipolitic enzymes activity and fatty acids oxidation intensity are known to be main age-related changes of lipid metabolism $[42,43]$. In our study, significant positive correlation between apoE and total cholesterol levels was observed in both men and women. This shows that age dynamics of plasma apoE levels in residents of the European North of Russia was primarily due to changes of total cholesterol concentration. Thus the increase of plasma apoE levels in the elder age groups in our study can be considered as a compensation of age-related changes in lipid metabolism.

In comparison with other studies, apoE levels in residents of the European North of Russia were low. In view of the variety of methods and calibrators used for apoE measurements it is difficult to compare the results received in our study with data of the literature. The apoE values reported in different studies vary widely [23]. In general, the mean values for apoE obtained by radioimmunoassay ranged from 3.6 to $6.0 \mathrm{mg} / \mathrm{dl}[33,44]$. However, some authors reported higher results $[45,46]$. For enzyme-linked immunosorbent assay the average values of apoE found by different authors can be divided into two groups: between 2.0 and $4.0 \mathrm{mg} / \mathrm{dl}[47,48]$ and between 5.0 and $9.5 \mathrm{mg} / \mathrm{dl}[49,50]$. Electroimmunoassay gives mostly the highest values, ranging from 6.7 to $11.9 \mathrm{mg} / \mathrm{dl}$ $[51,52]$. The reported mean concentrations of serum (plasma) apoE measured by immunoturbidimetry in control subjects are between 3.5 and $4.9 \mathrm{mg} / \mathrm{dl}[23,25,36]$.

The most suitable and interesting results were received in a large international study where a comparative estimation of apoE levels in blood among subjects from six countries of the Europe has been carried out [25,35]. According to results of this study, there is a north-south increasing gradient of apoE concentrations. The lowest apoE levels were observed in residents of Finland. ApoE concentrations $(3.69 \mathrm{mg} / \mathrm{dl}$ in men and $3.56 \mathrm{mg} / \mathrm{dl}$ in women) in blood in residents of Finland (45-64 years old) were comparable to our results obtained for agematched residents of the European North of Russia. In opinion of some authors, apoE concentration in blood is defined by the hepatic apoE production rate, not by apoE residence time in blood [20,53]. Thus, it is possible to assume that residents of the European North of Russia have a low apoE production.
The lower plasma levels of apoE in residents of the European North of Russia can be caused by features of the lipid metabolism. Lipid metabolism in residents of the North is characterized by a number of specific features due to the increased role of lipids in the energy metabolism of the human organism and specific transformations of some metabolic pathways. The alterations of energy metabolism in residents of high latitudes can be characterized as «the change-over from carbohydrate-type metabolism to the lipid one» [54]. One of the most illustrative manifestations of this phenomenon is the increase of the levels of triglycerides and VLDL in the blood of northerners. Thus low values of apoE in residents of the European North of Russia can be considered as adaptive changes providing metabolic transformation to activate lipid energy.

\section{Conclusion}

A shift in plasma apoE levels towards lower values is characteristic for residents of the European North of Russia. Plasma apoE levels below the normal values have been observed in approximately half of the examined northerners. The low values of apoE in residents of the European North of Russia can be connected with the specific features of lipid metabolism. Thus results of this study provide additional evidence of adaptive changes of lipid metabolism in residents of the North. The received values of apoE in residents of the European North of Russia should be considered in studies of lipid metabolism in the northerners.

\section{Abbreviations}

apoE: Apolipoprotein-E; BMI: Body mass index; VLDL: Very low density lipoproteins; HDL: High density lipoproteins.

\section{Competing interests}

The authors declare that they have no competing interests.

\section{Authors' contributors}

ERB and JOO were responsible for the initial conception and design of the study. NNP coordinated the blood samples collection and performed analyses. AMK contributed to the statistical analysis and interpretation data and wrote the first draft of the paper. All authors contributed to the critically revision of the article and approved the final published version to be published. All authors read and approved the final manuscript.

\section{Author details}

1 Institute of Physiology, Komi Science Center, Ural Branch of Russian Academy of Sciences, Pervomaiskaya av. 50, Syktyvkar 167982, Russia. ${ }^{2}$ Faculty of Health Sciences, University of Tromso, Tromso NO-9037Norge, Norway.

Received: 21 January 2013 Accepted: 21 March 2013

Published: 27 March 2013

\section{References}

1. Rall SC, Weisgraber KH, Mahley RW: Human apolipoprotein E. The complete amino acid sequence. J Biol Chem 1982, 257:4171-4178.

2. Shore B, Shore V: Heterogeneity of human plasma very low density lipoproteins. Biochemistry 1973, 12:502-507.

3. Havel RJ, Kotite L, Vigne JL, Kane JP, Tun P, Phillips N, Chen GC: Radioimmunoassay of human arginine-rich apolipoprotein, 
apolipoprotein E. Concentration in blood plasma and lipoproteins as affected by apoprotein E-3 deficiency. J Clin Invest 1980, 66:1357-1362

4. Mahley RW, Innerarite TL, Rall SC, Weisgraber KH: Plasma lipoproteins: apolipoprotein structure and function. J Lipid Res 1984, 25:1277-1294.

5. Mahley RW: Apolipoprotein E: cholesterol transport protein with expanding role in cell biology. Science 1988, 240:622-630.

6. Williams DL, Dowson PA, Newman TC, Rudel LL: Synthesis of apolipoprotein by peripheral tissues. Ann. NY Acad Sci 1985, 455:222-229.

7. Funke H, Boyles J, Weisgraber KH, Ludwig EH, Hui DY, Mahley RW: Uptake of apolipoprotein E-containing high density lipoproteins by hepatic parenchymal cells. Arteriosclerosis 1984, 4:452-461.

8. Koo C, Innerarity TL, Mahley RW: Obligatory role of cholesterol and apolipoprotein $\mathrm{E}$ in the formation of large cholesterol-enriched and receptor-active high density lipoproteins. J Biol Chem 1985, 260:11934-11943.

9. Eisenberg S: High density lipoprotein metabolism. J Lipid Res 1984, 25:1017-1058.

10. Vogel T, Guo NH, Guy R, Drezlich N, Krutzsch HC, Blake DA, Panet A, Roberts DD: Apolipoprotein E: a potent inhibitor of endothelial and tumor cell proliferation. J Cell Biochem 1994, 54:299-308.

11. Hayek T, Oiknine J, Brook JC, Aviram M: Increased plasma and lipoprotein lipid peroxidation in apo E-deficient mice. Biochem Biophys Res Commun 1994, 201:1567-1574.

12. Mabile L, Lefebvre C, Lavigne J, Boulet L, Davignon J, Lussier-Cacan S, Bernier L: Secreted apolipoprotein E reduces macrophage-mediated LDL oxidation in an isoform-dependent way. J Cellular Biochemistry 2003, 90:766-776.

13. Pham T, Kodyawala A, Hui DY: The receptor binding domain of apolipoprotein $\mathrm{E}$ is responsible for its antioxidant activity. Biochemistry 2005, 44:7577-7582

14. Kelly ME, Clay MA, Mistry MJ, Hsieh-Li HM, Harmony JA: Apolipoprotein E inhibition of proliferation of mitogen-activated T lymphocytes: production of interleukin 2 with reduced biological activity. Cell Immunol 1994, 159:124-139.

15. Ali K, Middleton M, Pure E, Rader DJ: Apolipoprotein E suppresses the type I inflammatory response in vivo. Circ Res 2005, 97:922-927.

16. Boiko ER, Kaneva AM: Apoprotein $\mathrm{E}$ and its availability in clinical physiology. Usp Fiziol Nauk 2009, 40:3-15.

17. Hofker MH, van Vlijmen BJ, Havekes LM: Transgenic mouse models to study the role of APOE in hyperlipidemia and atherosclerosis. Atherosclerosis 1998, 13:1-11.

18. Bock HH, Herz J, May P: Conditional animal models for the study of lipid metabolism and lipid disorders. Handb Exp Pharmacol 2007, 178:407-439.

19. Huang Y, Ji Z-S, Brecht WJ, Rall SC, Taylor JM, Mahley RW: Overexpression of apolipoprotein E3 in transgenic rabbits causes combined hyperlipidemia by stimulating hepatic VLDL production and impairing VLDL lipolysis. Arterioscler Thromb Vasc Biol 1999, 19:2952-2959.

20. Mahley RW, Huang Y, Rall SC: Pathogenesis of type III hyperlipoproteinemia (dysbetalipoproteinemia): questions, quandaries, and paradoxes. J Lipid Res 1999, 40:1933-1949.

21. Utermann G, Hees M, Steinmetz A: Polymorphism of apolipoprotein E and occurrence of dysbetalipoproteinaemia in man. Nature 1977, 269:604-607.

22. Breslow JL: Apolipoprotein genetic variation and human disease. Physiol Rev 1988, 68:85-132.

23. Siest G, Pillot T, Regis-Bailly A, Leininger-Muller B, Steinmetz J, Galteau MM, Visvikis S: Apolipoprotein E: an important gene and protein to follow in laboratory medicine. Clin Chem 1995, 41:1068-1086.

24. Mahley RW, Rall SC: Apolipoprotein E: far more than a lipid transport protein. Annu Rev Genomics Hum Genet 2000, 1:507-537.

25. Haddy N, De Bacquer D, Chemaly MM, Maurice M, Ehnholm C, Evans A, Sans S, Martins MC, De Backer G, Siest G, Visvikis S: The importance of plasma apolipoprotein $\mathrm{E}$ concentration in addition to its common polymorphism on inter-individual variation in lipid levels: results from Apo Europe. Europ J Hum Genetics 2002, 10:841-850

26. Liberopoulos EN, Miltiadous GA, Cariolou M, Tselepis AD, Siamopoulos KC, Elisaf MS: The influence of serum apolipoprotein $E$ concentration and polymorphism on serum lipid parameters in hemodialysis patients. Am J Kidney Dis 2004, 442:300-308.

27. Kobori S, Nakamura N, Uzawa H, Shichiri M: Influence of apolipoprotein E polymorphism on plasma lipid and apolipoprotein levels, and clinical characteristics of type III hyperlipoproteinemia due to apolipoprotein $\mathrm{E}$ phenotype E2/2 in Japan. Atherosclerosis 1988, 69:81-88.
28. Hanis CL, Hewett-Emmett D, Douglas TC, Bertin TK, Schull WJ: Effects of the apolipoprotein E polymorphism on levels of lipids, lipoproteins, and apolipoproteins among Mexican-Americans in Starr County, Texas. Arterioscler Thromb 1991, 11:362-370.

29. Gerdes LU, Klausen IC, Sihm I, Faergeman O: Apolipoprotein E polymorphism in a Danish population compared to findings in 45 other study populations around the world. Genet Epidemiol 1992, 9:155-167.

30. Gregg RE, Zech LA, Schaefer EJ, Brewer HB: Apolipoprotein E metabolism in normolipoproteinemic human subjects. J Lipid Res 1984, 25:1167-1176.

31. Au YPT, Bren ND, Kottke BA: A rapid apolipoprotein $E$ radioimmunoassay using solid-phase Staphylococcus protein. Use of pooled plasma as a secondary standard. Biochem Biophys Res Commun 1986, 138:455-462.

32. Liu M, Liu B: Serum apolipoprotein E levels in 238 healthy adults and 161 hyperlipidemic subjects in Chengdu area. Hua Xi Yi Ke Da Xue Xue Bao 1992, 23:261-263.

33. Phillips NR, Havel RJ, Kane JP: Sex-related differences in the concentrations of apolipoprotein $\mathrm{E}$ in human blood plasma and plasma lipoproteins. J Lipid Res 1983, 24:1525-1531.

34. Noma A, Hata Y, Goto Y: Quantitation of serum apolipoprotein A-I, A-II, B, C-II, C-III and $E$ in healthy Japanese by turbidimetric immunoassay: reference values, and age- and sex-related differences. Clin Chim Acta 1991, 199:147-157.

35. Schiele F, De Bacquer D, Vincent-Viry M, Beisiegel U, Ehnholm C, Evans A, Kafatos A, Martins MC, Sans S, Sass C, Visvikis S, De Backer G, Siest G: Apolipoprotein E serum concentration and polymorphism in six European countries: the ApoEurope project. Atherosclerosis 2000, 152:475-488.

36. Vincent-Viry M, Schiele F, Gueguen R, Bohnet K, Visvikis S, Siest G: Biological variations and genetic reference values for apolipoprotein $\mathrm{E}$ serum concentrations: results from the STANISLAS cohort study. Clin Chem 1998, 44:957-965

37. Bang HO, Dyerberg J, Nielsen AB: Plasma lipid and lipoprotein pattern in Greenlandic West-coast Eskimos. Lancet 1971, 1:1143-1145.

38. Boiko ER, Tkachev AV: The characteristics of lipid metabolism in permanent residents of the North. Fiziol Cheloveka 1994, 20:136-142.

39. Wang X, Magkos F, Mittendorfer B: Sex differences in lipid and lipoprotein metabolism: it's not just about sex hormones. J Clin Endocrinol Metab 2011, 96:885-893

40. Patsch W, Kim K, Wiest W, Schonfeld G: Effects of sex hormones on rat lipoproteins. Endocrinology 1980, 107:1085-1094.

41. Srinivasan SR, Wattigney W, Webber LS, Berenson GS: Serum apolipoprotein E in children and adolescents: the Bogalusa Heart Study. Metabolism 1989, 38:1173-1178.

42. Millar JS, Lichtenstein AH, Cuchel M, Dolnikowski GG, Hachey DL, Cohn JS, Schaefer EJ: Impact of age on the metabolism of VLDL, IDL, and LDL apolipoprotein B-100 in men. J Lipid Res 1995, 36:1155-1167.

43. Toth MJ, Tchernof A: Lipid metabolism in the elderly. Eur J Clin Nutr 2000, 54:121-125.

44. Blum CB, Aron L, Sciacca R: Radioimmunoassay studies of human apolipoprotein E. J Chin Invest 1980, 66:1240-1250

45. Yamada N, Murase T, Akanuma Y, Itakura H, Kosaka K: Plasma apolipoprotein E levels in hypertriglyceridemia. Horm Metab Res 1982, 14:303-306.

46. Holmquist $L$ : Quantitation of human serum very low density apolipoproteins C-I, C-II, C-III and E by enzyme immunoassay. J Immunol Methods 1980, 34:243-251.

47. Alsayed N, Rebourcet R, Chapman J: Concentrations of apoproteins CII, CIII, and E in total serum and in the apoprotein B-containing lipoproteins, determined by a new enzyme-linked immunosorbent assay. Clin Chem 1990, 36:2047-2052.

48. Bury J, Vercaemst R, Rosseneu M, Belpaire F: Apolipoprotein E quantified by enzyme-linked immunosorbent assay. Clin Chem 1986, 32:265-270.

49. Gracia V, Fiol C, Hurtado I, Pinto X, Argimon JM, Castineiras MJ: An enzymelinked immunosorbent assay method to measure human apolipoprotein E levels using commercially available reagents: effect of apolipoprotein $E$ polymorphism on serum apolipoprotein E concentration. Anal Biochem 1994, 223:212-217

50. Carlsson J, Armstrong WW, Reiber H, Felgenhauer K, Seidel D: Clinical relevance of the quantification of apolipoprotein $E$ in cerebrospinal fluid. Clin Chim Acta 1991, 196:167-176.

51. Avogaro P, Bittolo Bon G, Gazzolato G, Pontoglio E, Kostner GM: Distribution and concentration of apolipoprotein $E$ in high and low density lipoproteins. Ric Clin Lab 1983, 13:431-436. 
52. Bittolo Bon G, Cazzolato G, Saccardi M, Kostner GM, Avogaro P: Total plasma apo $E$ and high density lipoprotein apo $E$ in survivors of myocardial infarction. Atherosclerosis 1984, 53:69-75.

53. Millar JS, Mayer J, Lichtenstein AH, Dolnikowski GG, Ordovas JM, Schaefer EJ: Apo $\mathrm{E}$ and apo $\mathrm{B} 100$ kinetics in triglyceride-rich lipoproteins and their role in LDL production. Circulation 1998, 98:305-306.

54. Panin LE: Human homeostasis in high-latitude environment. Alaska Med 2007, 49:25-28.

doi:10.1186/1476-511X-12-43

Cite this article as: Kaneva et al:: Plasma levels of apolipoprotein-E in residents of the European North of Russia. Lipids in Health and Disease 2013 12:43.

\section{Submit your next manuscript to BioMed Central and take full advantage of:}

- Convenient online submission

- Thorough peer review

- No space constraints or color figure charges

- Immediate publication on acceptance

- Inclusion in PubMed, CAS, Scopus and Google Scholar

- Research which is freely available for redistribution 